УДК 621.313.048

Кандидати техн. наук С.І. Яцько (УкрДАЗТ), В.В. Карпенко, асп. Д.Ю. Василенко (ДП «Електроваэммаш»

\title{
ОБГРУНТУВАННЯ ВИБОРУ МЕТОДІВ КОНТРОЛЮ НАГРІВОСТІЙКОСТІ ТЯГОВИХ ЕЛЕКТРИЧНИХ МАШИН
}

\author{
Представив д-р техн. наук, профессор А.П. Фалендиш
}

Вступ. Надійність електрообладнання електрорухомого складу значною мірою залежить від температурного режиму його роботи. Термічні навантаження не тільки додатково навантажують елементи електрообладнання, але i знижують їх міцнісні характеристики [1].

Однією 3 причин зростання відмов тягових електричних машин (ТЕМ) в експлуатації, особливо у гарантійний строк, $\epsilon$ недосконалість існуючих стандартних методів випробувань систем ізоляції ТЕМ в умовах виробництва через невідповідність ï сучасним вимогам до надійності та стійкості систем ізоляції до зовнішніх чинників, нормам безпеки. Це обумовлює необхідність проведення їх ретельного аналізу та удосконалення.
Аналіз останніх досліджень i публікацій. Останнім часом дослідженню впливу підвищеної температури на ізоляцію ТЕМ в експлуатації приділялася значна увага різними науковими колективами. Такі дослідження проводили А.М. Худоногов, I.В. Бірюков, В.I. Бочаров, З.Г. Гіоєв, М.Д. Глущенко, А.А. Зарифьян, Д.Д. Захарченко, В.А. Кучумов, А.Л. Курочка, А.Л. Лісіцин, В.Б. Медель, М.Д. Находкін, А.Н. Савоськін, В.П. Феоктістов, В.А. Четвергов, В.Г. Щербаков, А.В. Голговських, І.С. Гамаюнов, Д.А. Оленцевич, М.А. Грищенко.

Значний внесок у вирішення питань надійності найбільш «слабких вузлів ТЕМ» - колекторно-щіткового вузла та ізоляційних конструкцій тягових електродвигунів - зробили В.Д. Авілов, 
Г.Б. Дурандін, А.А. Бакланов, М.Ф. Карасьов, Ш.К. Ісмаілов, А.С. Космодаміанський, А.С. Серебряков, А.Т. Осяєв, В.П. Смірнов та ін.

Був проведений аналіз надійності рухомого складу залізниць, який показав, що більша частина відмов припадає на тягові електродвигуни (ТЕД). Спостерігається подальше зниження надійності ТЕД. Більше половини пошкоджень ТЕД припадає на ізоляційні конструкції.

У роботах указаних авторів розроблено математичні моделі теплового стану в ТЕД, які дозволяють досліджувати процеси нагрівання обмоток ТЕД при різних теплових режимах, та визначено ступінь i характер впливу особливостей кліматичних умов зовнішнього середовища на механізм пошкодження ізоляції ТЕД, уточнено процес зміни надійності ізоляції в залежності від експлуатаційних дій - зміни властивостей ізоляції під дією підвищеної температури, розроблено заходи i рекомендації 3 удосконалення системи технічного утримання ізоляції ТЕД 3 урахуванням особливостей кліматичних умов навколишнього середовища. Запропоновано технології безперервного моніторингу та підтримання потрібного температурного режиму ізоляції ТЕД із застосуванням сучасної техніки.

Але до нашого часу не приділялася належна увага проблемі забезпечення теплостійкості ізоляції при виготовленні TEM. Стандартні методи випробувань ТЕМ на теплостійкість не перероблялись 3 80-х років минулого сторіччя. Потрібно визначити допустимі значення показників при випробуваннях ТЕМ та методи їх отримання, які б забезпечували надійність ТЕМ в експлуатації.

Мета роботи. Обгрунтування вибору та удосконалення методів контролю та випробувань нагрівостійкості TEM, які відповідають сучасним вимогам та забезпечуватимуть високу надійність ТЕМ в експлуатації.
Матеріал і результати дослідження. Вибір методів випробувань ТЕМ на стійкість до дії верхнього робочого значення температури довкілля здійснюється за наведеною на рис. 1 схемою нормативної документації, що встановлює ці методи.

ТЕМ відносяться до тепловидільних виробів, що нагріваються, тому метод 201-1.1 (випробування нетепловидільних виробів) не придатний для вищезазначеного випробування.

Застосовування методів 201-2.1 і 201-2.2, що передбачають випробування в камері під електричним навантаженням тепловидільних виробів ускладнено, оскільки кліматичні камери і їх агрегати не розраховані на випробування ТЕМ, що працюють під електричним навантаженням.

У випробувальному центрі тягового електрообладнання ДП завод «Електроважмаш», м. Харків, атестат акредитації № ССФЖТ UA.01ЖТ.12ЦТ.00181 від $\quad 07.12 .2009$ p., $\quad$ випробування проводиться за методом 201-1.2 випробування тепловидільних виробів у камері без електричного навантаження.

Пропонується в перспективі ці випробування замінити на метод 201-3 випробування тепловидільних виробів під електричним навантаженням поза камерою. Метод 201-3 передбачає застосування навантажень, більш ідентичних навантаженням на ТЕМ в експлуатації в порівнянні з методом 201-1.2 тому, що даний метод дозволяє використовувати струм як один 3 основних показників, 3 яких може бути встановлена адекватність режимів стендових випробувань експлуатаційним режимам. Як вказано в [1], тепловий режим силового обладнання при постійній температурі довкілля на даній позиції регулювання швидкості локомотива визначається у підсумку струмом двигуна. За методом 201-3 випробування проводять поза камерою, тому у перспективі слід розробити метод 
імітації верхнього значення температури довкілля при випробуванні цим методом.

Упровадження цього методу планується після накопичення по ньому дослідних даних і проведення модернізації випробувальних стендів, на яких проводяться випробування ТЕМ на нагрівання.

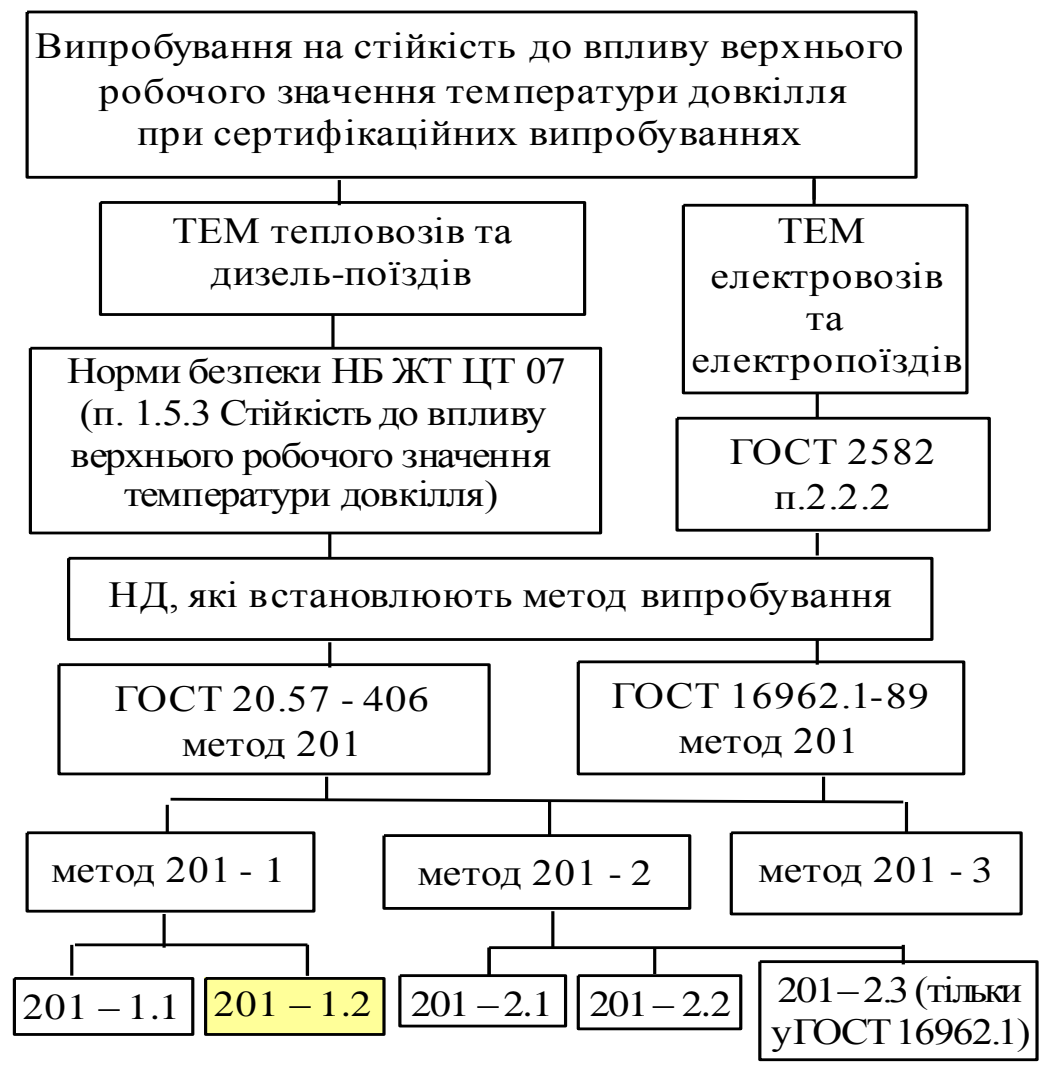

Рис. 1. Схема випробувань ТЕМ за методом 201

Застосовуваний нині метод $201-1.2 \epsilon$ жорсткішим у порівнянні з методом 201-3. Це пов'язано 3 тим, що : 1) усі вузли, обмотки і система ізоляції за всім обсягом нагріваються до максимальної температури найбільш нагрітих частин ТЕМ із збільшенням температури довкілля i витримуються в камері в нагрітому стані при такій температурі декілька годин; 2) не передбачається підведення в ТЕМ на обмотки повітря, що охолоджує; 3) зовні на ТЕМ впливає повітря, що має максимальну температуру найбільш нагрітих частин TEM, а не верхнє значення температури в експлуатації $+40^{\circ} \mathrm{C}$.

Істотний недолік методу 201-1.2. Згідно $з$ табл. 1 [2] обмотка якоря, обмотка збудження i колектор 3 відповідними класами нагрівостійкості ізоляції електричної машини мають гранично допустимі перевищення температури, що істотно відрізняються між собою (наприклад, клас нагрівостійкості ізоляції $\mathrm{H}$ : обмотки якоря $160{ }^{\circ} \mathrm{C}$, обмотки збудження $-180{ }^{\circ} \mathrm{C}$, колектора $-105{ }^{\circ} \mathrm{C}$ за ГОСТ 2582-81). Нагрівання усієї електричної машини за методом 201-1.2 може привести до перегрівання колектора й обмоток якоря. Крім того, мастило підшипників та деталі ТЕМ, які виготовлені 3 гумово-технічних матеріалів та пластмас, не розраховані на максимальні температури нагрівання i підлягають заміні після випробувань. Слід враховувати, що 
світовий досвід говорить про те, що у перспективі будуть упроваджуватися системи ізоляції ще більш високого класу нагрівостійкості $200{ }^{\circ} \mathrm{C}, \quad 220^{\circ} \mathrm{C}$ i актуальність цього питання буде зростати.

Розглянемо експериментальні дані температур нагрівання основних вузлів тягових електродвигунів при тривалому режимі роботи на прикладі тягового двигуна ЭДП810У1 (клас ізоляції Н) для вантажних электровозів $2 Э С 6$.
На рис. 2 показано розподіл температур на внутрішніх поверхнях нагрітих ТЕД після приймально-здавальних випробувань. Зображення отримані за допомогою цифрового тепловізора фірми FLUKE (Федеративна Республіка Німеччина). Із зображень видно, що температури нагрівання якоря, головних полюсів та колектора дійсно істотно відрізняються між собою.

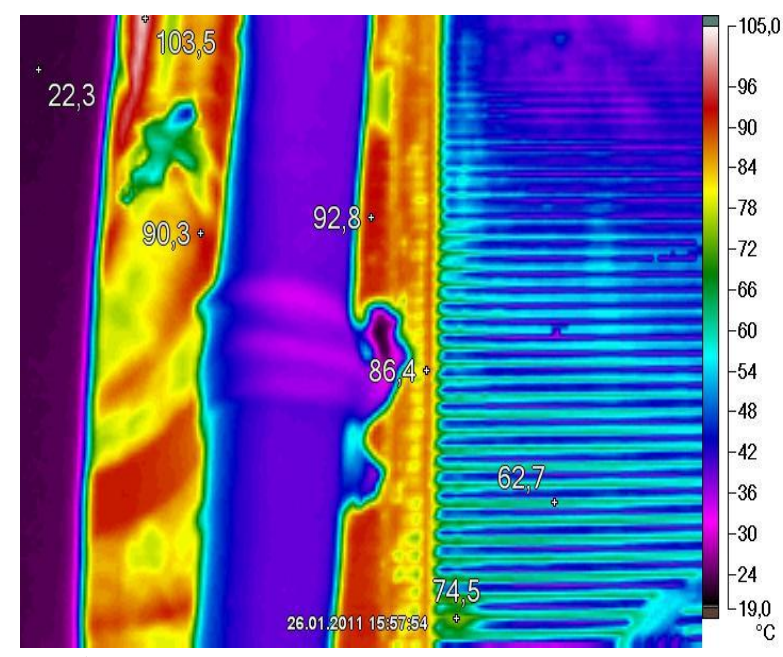

a)

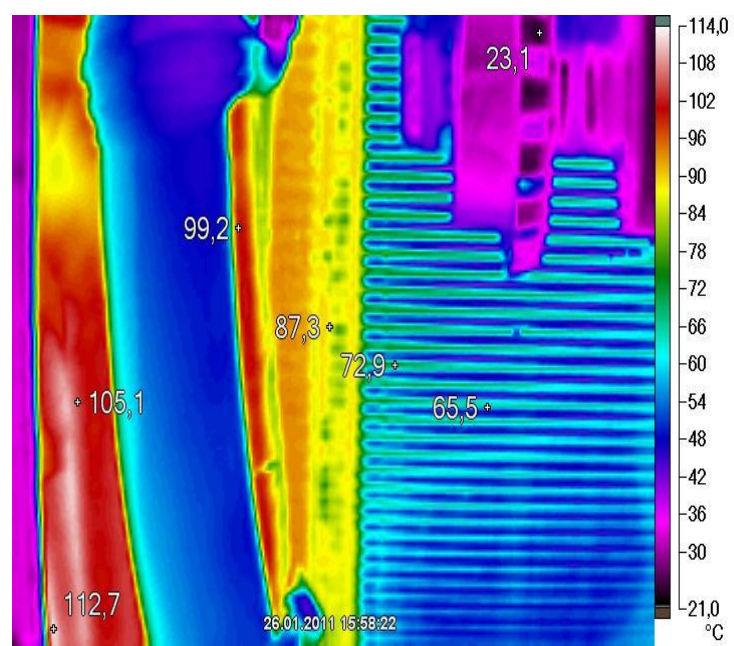

б)

Рис. 2. Розподіл температур на внутрішніх поверхнях двигунів ЕДП810У1 після випробувань на нагрівання: a - після роботи в режимі генератора; б - після роботи в режимі двигуна

Найбільш нагрітими частинами ТЕД $\epsilon$ головні полюси $-+90,3 \div+103,5^{\circ} \mathrm{C}$ для двигуна, що працював у режимі генератора, та $+105,1 \div+112,7^{\circ} \mathrm{C}$ для двигуна, що працював у режимі двигуна 3 навантаженням. Видно також край обмотки якоря, температура якого відповідно для першого та другого двигунів $+92,8^{\circ} \mathrm{C}$ та $+99,2^{\circ} \mathrm{C}$. Температура колекторів ТЕД значно менша $\left(62,7^{\circ} \mathrm{C} \div 74,5^{\circ} \mathrm{C}\right.$ та $65,5^{\circ} \mathrm{C}$ $\div 72,9^{\circ} \mathrm{C}$ для першого та другого ТЕД відповідно).

Випробування ТЕМ в зборі на відповідність класу нагрівостійкості ізоляції неможливе, оскільки, як вказано раніше, обмотка збудження, обмотка якоря і колектор, згідно ГОСТ з $2582-81$, мають різні перевищення температури, що гранично допускаються для одного і того ж класу нагрівостійкості, а TЕМ в зборі при випробуваннях необхідно нагрівати до якої-небудь конкретної температури. Якщо виріб має складальні одиниці 3 різними класами нагрівостійкості ізоляції або 3 різними перегріваннями, випробування ведуть по $\mathrm{T}=(\tau+\mathrm{t}){ }^{\circ} \mathrm{C}$ найбільш нагрітої складальної одиниці, де $\tau$ - максимальна температура найбільш нагрітої частини TEM, отримана при приймальноздавальних випробуваннях, $\mathrm{t}$ - верхнє значення температури довкілля, рівне +40 ${ }^{\circ} \mathrm{C}$ (згідно з ГОСТ 15150, п. 3.2, табл. 3). 
У Випробувальному центрі тягового електрообладнання ДП завод "Електроважмаш" установлено на усі ТЕМ допустиме значення опору ізоляції обмоток ТЕМ відносно корпусу і між обмотками 1,0 МОм у режимі дії верхнього значення температури довкілля при стабілізованій температурі виробу $110 \pm 1^{\circ} \mathrm{C}$, яке отримано розрахунковим шляхом i підтверджено багаторічним практичним досвідом.

Відповідно до закону Арреніуса [3] при підвищенні температури ізоляції на кожні $10^{\circ} \mathrm{C}$ їі ресурс знижується приблизно в 2 рази, тобто при підвищенні температури в 10 n разів іiі ресурс знизиться в $2^{\mathrm{n}}$ разів. За даними попередніх досліджень це правило виконується і для опору ізоляції при іii нагріванні, тобто

$$
\mathrm{R}_{\mathrm{i} 3+20+10 \mathrm{n}}=\mathrm{R}_{\mathrm{i3}+20} / 2^{\mathrm{n}} .
$$

Опір системи ізоляції відносно корпусу і між обмотками більшості ТЕМ тепловозів і електровозів за нормальних кліматичних умов (н.к.у.) $\mathrm{t}^{\mathrm{o}}=20 \pm 10^{\circ} \mathrm{C}$, $\alpha=45-80 \%$ знаходиться в межах 20006000 МОм (допустиме значення 20 МОм за нормами безпеки НБ ЖТ ЦТ-07) [4].

Розрахунок для мінімального опору ізоляції за нормальних кліматичних умов 2000 Мом:

\begin{tabular}{|c|c|}
\hline Температура нагрівання & Опір ізоляції \\
\hline від $+20^{\circ} \mathrm{C}$ до $+110^{\circ} \mathrm{C}$ & $\mathrm{R}_{\mathrm{i} 3+110}=\mathrm{R}_{\mathrm{i}+20} / 2^{9}=2000 / 512=3,91 \mathrm{MOM}$ \\
\hline до $+140^{\circ} \mathrm{C}$ & $\mathrm{R}_{\mathrm{i} 3+140}=\mathrm{R}_{\mathrm{i} 3+20} / 2^{12}=2000 / 4096=0,488 \mathrm{MOM}$ \\
\hline до $+160^{\circ} \mathrm{C}$ & $\mathrm{R}_{\mathrm{i}_{3}+160}=\mathrm{R}_{\mathrm{i} 3+20} / 2^{14}=2000 / 16384=0,122 \mathrm{MOM}$ \\
\hline до $+180^{\circ} \mathrm{C}$ & $\mathrm{R}_{\mathrm{i} 3+180}=\mathrm{R}_{\mathrm{i} 3+20} / 2^{16}=2000 / 65536=0,031 \mathrm{MOM}$ \\
\hline
\end{tabular}

Дані експериментальних досліджень указують, що при нагріванні ТЕМ до стабілізованої температури $110^{\circ} \mathrm{C}$ достатньо нагрівостійка система ізоляції класів нагрівостійкості $\mathrm{F}, \mathrm{H}$ повинна мати опір не нижче 1 МОм, що підтверджено багаторічним досвідом випробувань ТЕМ.

На поданих нижче графіках (рис. 3) на прикладі генератора постійного струму (клас ізоляції $\mathrm{H}$ ) наведені залежності $\mathrm{Riz}=\mathrm{f}(\mathrm{t}+\tau)$ при нагріванні від $20^{\circ} \mathrm{C}$ до $180^{\circ} \mathrm{C}$ та при охолодженні до н.к.у., які отримані експериментально при випробуваннях зразків 1-3 за методом 201-1.2 ГОСТ 20.57-406 у порівнянні 3 розрахунковими значеннями, отриманими за формулою (1).

Випробування на нагрівання та охолодження проводилося за методом 201-1.2 на зразках генератора, які ще не були в експлуатації.

3 графіків видно, що фактичні показники Riз у більшості випадків перевищують розрахункове значення, що свідчить про достатньо високу нагрівостійкість ізоляції, особливо третій зразок.

Слід зазначити, що нагрівання ТЕМ до $180^{\circ} \mathrm{C}$ за методом 201-1.2 суперечить вимогам табл. 1 [2] і може призвести до перегрівання колектора і обмотки якоря. 3 одного боку, нагрівання вказаних частин TEM не призведе до виходу їх з ладу, тому що в технологічному процесі виготовлення такі температури мають місце, але можуть суттєво знизити їх ресурс в експлуатації. Крім того, як було сказано вище, в ТЕМ застосовуються гумово-технічні вироби, вироби 3 пластмас та інші, для яких температура $180{ }^{\circ} \mathrm{C} \epsilon$ недопустимою.

Вимір опору ізоляції при $+110^{\circ} \mathrm{C}$ проводиться під час охолодження ТЕМ, попередньо нагрітої до максимальної температури перегрівання обмоток при верхньому значенні температури довкілля, що дозволяє перевірити здатність системи ізоляції ТЕМ до відновлення опору до значення не менше 1 МОм. 

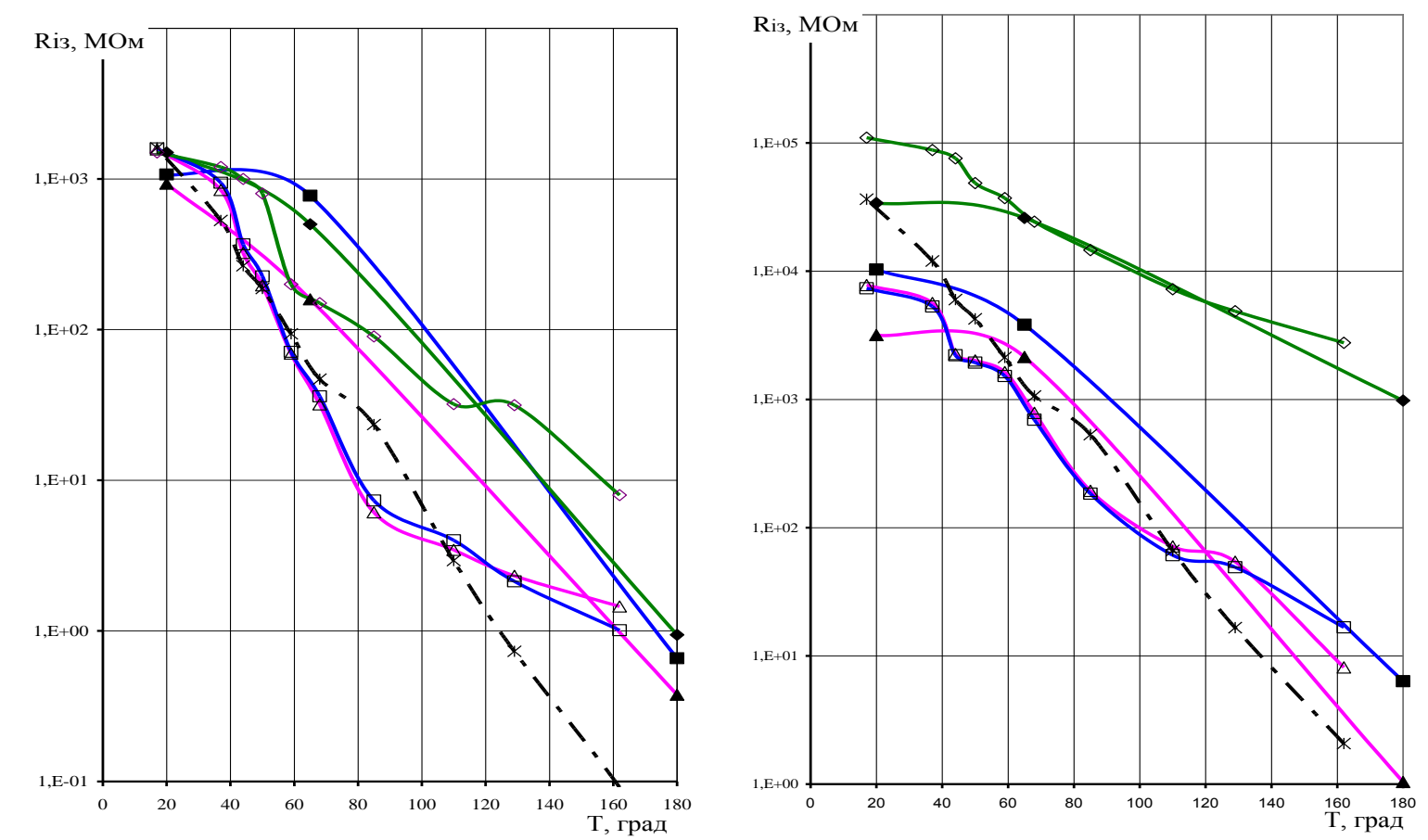

\begin{tabular}{|c|c|c|}
\hline $\begin{array}{c}\multimap \text { TEM } \\
\text { (нагрівання) }\end{array}$ & №1 & $\begin{array}{l}\triangle \\
\text { (охолодження) }\end{array}$ \\
\hline $\begin{array}{l}\rightarrow \text { TEM } \\
\text { (нагрівання) }\end{array}$ & №2 & $\begin{array}{l}\text { — TEM } \\
\text { (охолодження) }\end{array}$ \\
\hline $\begin{array}{l}\multimap \\
\text { (нагрівання) }\end{array}$ & №3 & $\begin{array}{l}\smile \text { TEM } \\
\text { (охолодження) }\end{array}$ \\
\hline
\end{tabular}

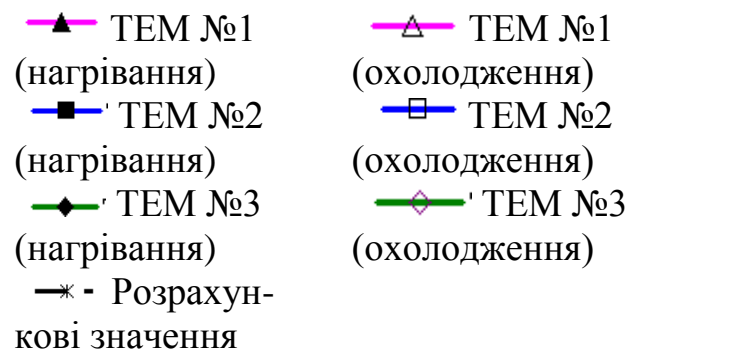

Розрахункові

значення

a)

б)

Рис. 3. Залежності величин опору ізоляції ТЕМ від дії підвищеної температури: a - ланцюг якоря; б - обмотка збудження

\section{Висновки i перспективи подаль- шого використання \\ 1. У роботі запропонована доцільність проведення випробування методом 201-3 замість методу 201-1.2 з точки зору набли- ження режимів випробування ТЕМ до реа- льних навантажень та умов експлуатації.}

2. Обгрунтовано вибір мінімального порога опору ізоляції $1 \mathrm{MOM}$ при стабілізованій температурі $+110^{\circ} \mathrm{C}$ при випробуваннях ТЕМ на стійкість до дії верхнього значення температури довкілля за методом $201-1.2$.

\section{Список літератури}

1. Исаев, И.П. Ускоренные испытания и прогнозирование надежности электрооборудования локомотивов [Текст] / И.П. Исаев, А.П. Матвеевичев, Л.Г. Козлов. М.: Издательство «Транспорт», 1984. - 245 с. 
2. Машины электрические вращающиеся тяговые. Общие технические условия [Текст]: ГОСТ 2582 - 81. - М.: ИПК Изд-во стандартов, 1981. - 34 с.

3. Кулаковский, В.Б. Работа изоляции в генераторах: Возникновение и методы выявления дефектов [Текст] / В.Б. Кулаковский. - М.: Энергоиздат, 1981. - 256 с.

4. Нормы безопасности НБ ЖТ ЦТ 07-99 «Тепловозы, дизель-поезда и автомотрисы (рельсовые автобусы). Электрооборудование тяговое. Нормы безопасности на железнодорожном транспорте» [Текст]. - Введ. Приказом Минтранса России от 11.02.2009 г. № 22. Приложение № 16. - М., 2009. - 290 с.

Ключові слова: випробування, нагрівання, температура, кліматична камера.

\section{Анотаціi}

Наводяться результати обгрунтування вибору методів контролю та випробувань тягових електричних машин на нагрівостійкість. Вказуються шляхи максимального наближення режимів стендових випробувань до експлуатаційних режимів в умовах підвищеної температури довкілля.

Приводятся результаты обоснования выбора методов контроля и испытаний тяговых электрических машин на нагревостойкость. Указываются пути максимального приближения режимов стендовых испытаний к эксплуатационным режимам в условиях повышенной температуры окружающей среды.

The results of substantiation of choice of methods of control and tests of hauling electric machines heat stability are resulted. The pathes of the maximal approaching of the modes of bench tests are specified to the operating modes in the conditions of the heightened ambient temperature. 